\title{
Giant renal artery pseudoaneurysm 18 months after blunt trauma
}

\section{Pseudoaneurisma gigante de artéria renal após 18 meses de trauma contuso}

Rodrigo Andrade Vaz de Melo ${ }^{1,2,3}$, Márcio José de Magalhães Pires ${ }^{1,3}$, Leandro Moreno Silveira Da Silva ${ }^{4}$, Angélica Baptista Segóvia3,

\begin{abstract}
Renal artery pseudoaneurysms are uncommon vascular lesions that require a high degree of suspicion because they are usually difficult to diagnose. Posttraumatic renal artery pseudoaneurysms should be treated because spontaneous resolution is extremely unusual, and the risk of aneurysm rupture is high. We describe the case of a patient who presented with a pulsatile mass in the right upper quadrant and recurrent abdominal pain 18 months after blunt trauma. Arteriography and multislice computed tomography angiography revealed a pseudoaneurysm measuring $22 \mathrm{~cm}$ in the right renal artery. The patient was successfully treated with conventional open surgery.
\end{abstract}

Keywords: giant pseudoaneurysm; renal artery; blunt trauma.

\section{Resumo}

Pseudoaneurismas de artéria renal são lesões vasculares pouco comuns, que geralmente demandam alto grau de suspeição, por serem de difícil diagnóstico. Considerando a baixa expectativa de resolução espontânea dos PARs pós-traumáticos, aliada ao importante risco de rotura, faz-se necessária a correção destas lesões. Apresentamos o caso de um paciente, vítima de trauma contuso há 18 meses, com queixa de massa pulsátil em hipocôndrio direito associado a dor abdominal recorrente. Depois da arteriografia e angiotomografia multislice, foi diagnosticado um pseudoaneurisma de artéria renal direita com $22 \mathrm{~cm}$ de extensão, sendo então submetido a tratamento cirúrgico por via aberta convencional, com sucesso terapêutico.

Palavras-chave: pseudoaneurisma gigante; artéria renal; trauma contuso.

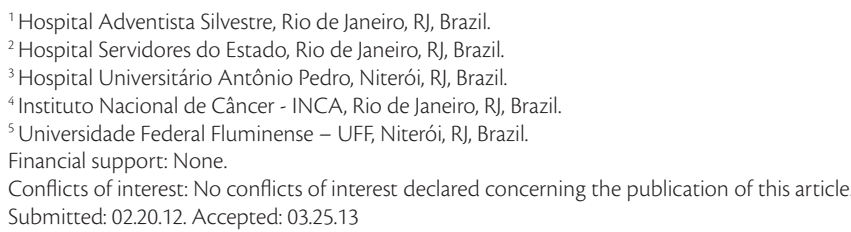




\section{INTRODUCTION}

Renal artery pseudoaneurysms (RAP) are rare vascular lesions that require a high index of suspicion because they are difficult to detect clinically and usually difficult to diagnose ${ }^{1,2}$. Studies in the literature suggest several etiologies, such as partial nephrectomy, percutaneous procedures, renal biopsy, penetrating trauma and, more rarely, blunt trauma ${ }^{1,3}$.

The risk of hemorrhage due to rupture is high, and surgical treatment is indicated because there are few reports of cases of spontaneous resolution of posttraumatic $\mathrm{RAP}^{4,5}$.

This study describes the case of a patient with a 22$\mathrm{cm}$ pseudoaneurysm diagnosed using arteriography and CT angiography 18 months after blunt trauma and treated using conventional open surgery.

\section{CASE REPORT}

A 70-year-old men had suffered blunt trauma due to a fall from a height of 4 meters about 18 months before presentation. At the time, he had a hip fracture and acute inferior vena cava thrombosis, treated with external fixation and a vena cava filter with a satisfactory clinical outcome.

In March 2009 he sought the Adventista Silvestre Hospital (Rio de Janeiro, Brazil) because of a pulsatile mass in the right upper quadrant and recurrent abdominal pain.

Examinations showed that the patient was hemodynamically stable; other findings were normal skin color and cardiac tests, swollen abdomen and collateral caval flow distribution (Figure 1). There was a large pulsatile mass in the right upper quadrant and no edema in lower extremities. He underwent diagnostic tests using arteriography (Figure 2) and selective angiography of visceral branches, which did not show any aneurysm formation, although the ostium of the right renal artery was not detected, and phlebography (Figure 3). After that, multislice CT angiography (Figure 4) revealed a giant aneurysm (22 $\mathrm{cm}$ ) in the right renal artery and a non-functioning right kidney.

The team responsible for the case chose the conventional treatment of renal artery pseudoaneurysm using midline laparotomy. Access to the inframesocolic aorta was especially difficult due to excessive collateral blood flow resulting for the occlusion of the infrarenal vena cava at the time of trauma. Therefore, proximal repair of the renal artery (Scott maneuver) was not feasible. The medical team chose access and exposure of the supraceliac aorta at the hiatus for later clamping and dissection of the anterior surface of the right renal artery pseudoaneurysm, which was laterally pushing back the suprarenal segment of the inferior vena cava. Supraceliac clamping was followed by the opening of the pseudoaneurysm and manual removal of the

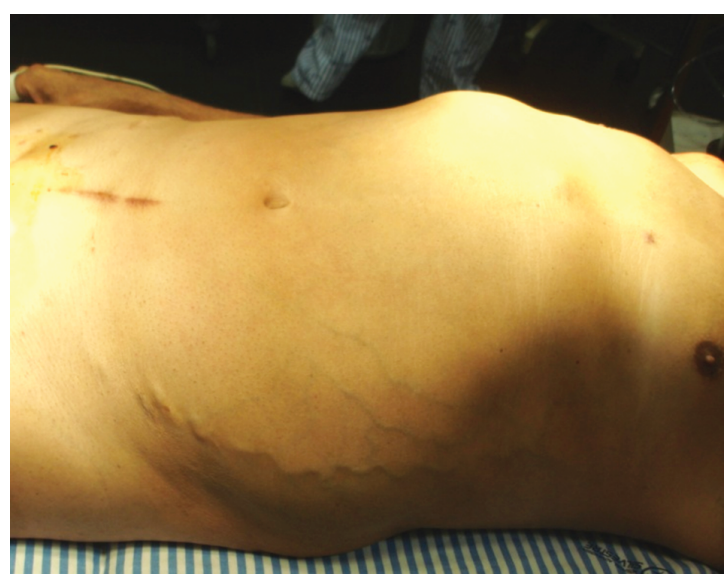

Figure 1. Swollen abdomen and important collateral blood flow.

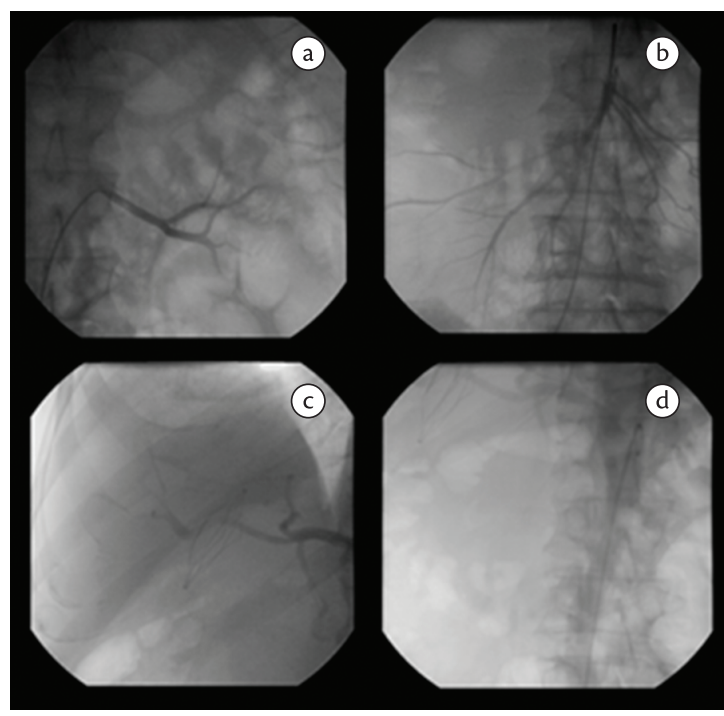

Figure 2. (a) left renal artery; (b) superior mesenteric artery; (c) hepatic artery; (d) hepatic artery; right renal artery ostium was not detected.

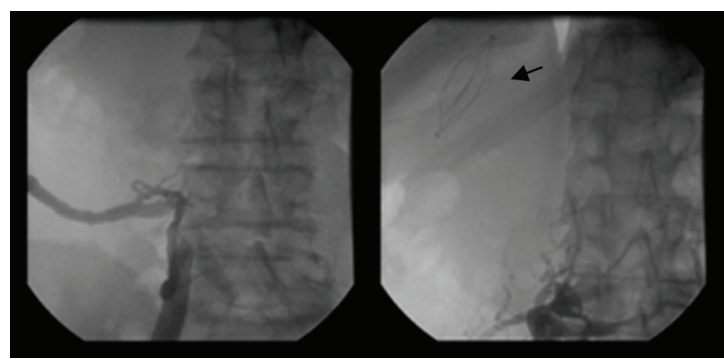

Figure 3. No flow in inferior vena cava, and vena cava filter displaced due to space-occupying process (arrow). 
thrombus, followed by internal suture of the right renal artery aortic at the ostium (Figures 5 and 6). Clamping time was about 3 minutes, and there was no significant hemodynamic repercussion. Postoperative progression was extremely satisfactory. The patient was discharged three days after admission.

\section{DISCUSSION}

Pseudoaneurysms of the renal artery due to trauma are rare entities. In general, the incidence of this type of lesion as a consequence of penetrating trauma is higher than that resulting from blunt trauma ${ }^{6,7}$. The mechanism of lesion is often the violation of the abdominal cavity during partial nephrectomy, percutaneous procedures, renal biopsy or penetrating trauma ${ }^{1,3}$. However, in blunt trauma, a sudden deceleration force may cause partial or full rupture of the renal artery walls. Adjacent structures, such as

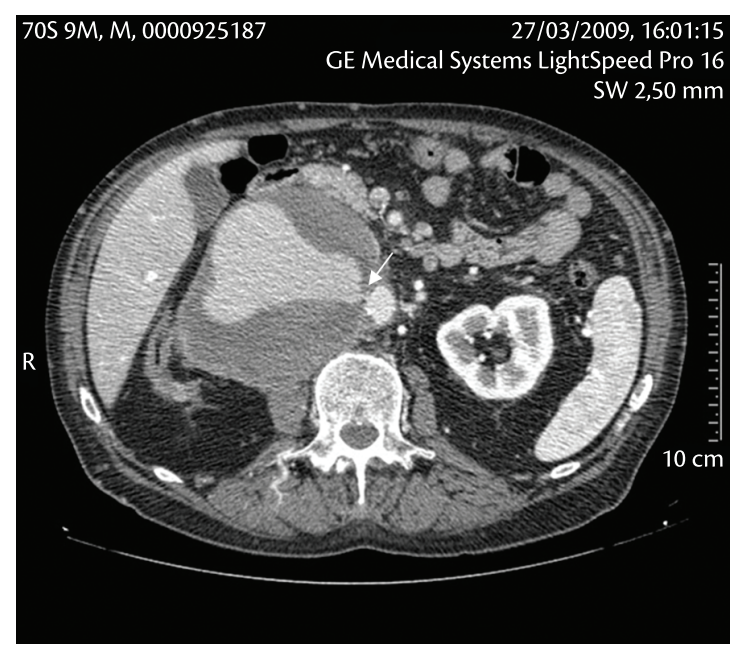

Figure 4. CT angiogram shows renal artery pseudoaneurysm. Arrow - renal artery ostium.

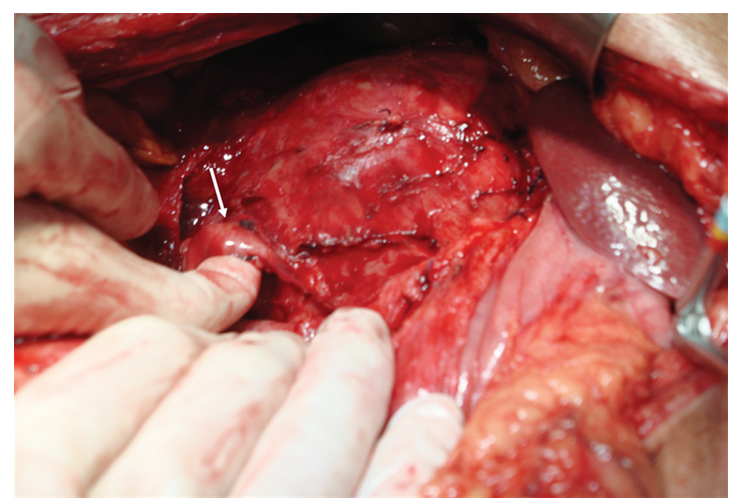

Figure 5. Right renal artery pseudoaneurysm and inferior vena cava with fibrosis (arrow). the Gerota's fascia and even the renal parenchyma, may help to contain the hematoma. Pseudoaneurysm formation is a consequence of recanalization between the extra- and intravascular spaces as a consequence of the deterioration of clots and necrotic tissues in the site $^{8}$. As normal hemodynamics is restored, RAP may grow and even rupture, which stresses the importance of treating these lesions.

The most common clinical signs and symptoms are gross hematuria, flank and lower back pain, hypertension and pulsatile abdominal mass. RAP should be part of the differential diagnosis for any patient with a history of trauma, surgery or renal biopsy that presents with flank pain and hematuria ${ }^{1,7}$. Currently, several imaging tests may be used for the diagnosis, such as Doppler ultrasound, CT angiography, renal scintigraphy and MRI. However, no test equals the diagnostic sensitivity of arteriography, with is currently the criterion standard to investigate these lesions ${ }^{8,9}$.

The chances of spontaneous resolution of posttraumatic RAP are low according to the literature, and there is a high risk of rupture. Therefore, these lesions should be repaired.

The treatment options to repair RAP are conventional open surgery and arterial embolization. However, no consensus about which procedure should be chosen was found in our review of the literature. Arterial embolization is often the procedure of choice for the treatment of small pseudoaneurysms in hemodynamically stable patients ${ }^{10,11}$. Some authors reported on the success of treatments using embolization for larger pseudoaneurysms, as in the cases reported by Albani et al. ${ }^{2}$ and Pastorín et al., ${ }^{1}$ in which case the lesion measured $10 \mathrm{~cm}$. Others, as Ansari et al., ${ }^{12}$ for example, chose open surgery for a RAP of the same size. We identified some

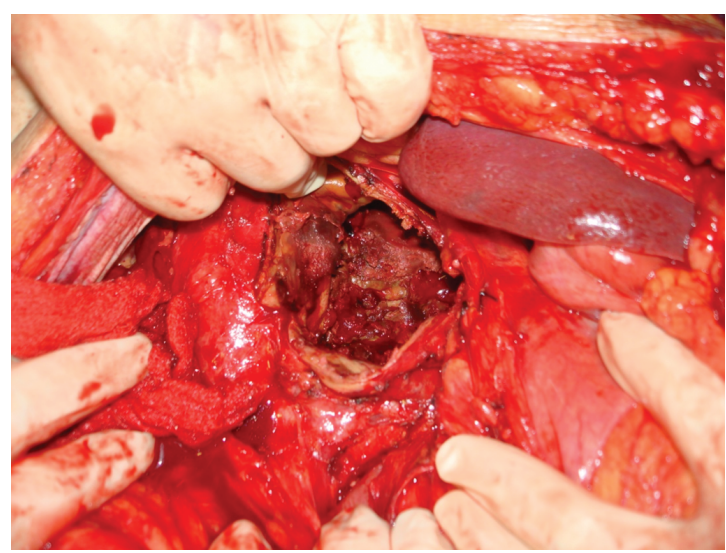

Figure 6. Dissected renal artery pseudoaneurysm. 
resistance to the use of embolization of large RAP due to the complexity of the anatomic region and the risk of complications, such as aneurysm rupture and parenchymal ischemia. Our patient had a $22-\mathrm{cm}$ pseudoaneurysm and a non-functioning kidney. Treatment was conventional open surgery because of the large size of the lesion, greater than all the others found in our review of the literature.

Although arterial embolization is a widely used technical resource to repair RAP, open surgery remains a safe and satisfactory option in case of giant pseudoaneurysms.

\section{REFERENCES}

1. Pastorín R, Rodríguez N, Polo $A M$, Vicente JM, Luján $M$. Posttraumatic giant renal pseudoaneurysm. Emerg Radiol. 2007 Jun;14(2):117-21. http://dx.doi.org/10.1007/s10140-007-0573-5

2. Albani JM, Novick AC. Renal artery pseudoaneurysm after partial nephrectomy: three case reports and a literature review. Urology. 2003 Aug;62(2):227-31. http://dx.doi.org/10.1016/ S0090-4295(03)00364-9

3. Shapiro EY, Hakimi AA, Hyams ES, Cynamon J, Stifelman $M$, Ghavamian R. Renal artery pseudoaneurysm following laparoscopic partial nephrectomy. Urology. 2009 Oct;74(4):819-23.

4. Madhusudhan KS, Sharma S, Seth A. Spontaneous closure of a traumatic intrarenal pseudoaneurysm. J Postgrad Med. 2009 Apr-Jun;55(2):124-6. http://dx.doi.org/10.4103/0022-3859.52844

5. Lee RS, Porter JR. Traumatic renal artery pseudoaneurysm: Diagnosis and management techniques. J Trauma 2003;55:972-8.

6. Jebara VA, El Rassi I, Achouh PE, Chelala D, Tabet G, Karam B. Renal artery pseudoaneurysm after blunt abdominal trauma. J Vasc Surg. 1998;27:362-365. http://dx.doi.org/10.1016/ S0741-5214(98)70368-4

7. Miller DC, Forauer A, Faerber G). Successful angioembolization of renal artery pseudoaneurysms after blunt abdominal trauma. Urology. 2002;59:444-6. http://dx.doi.org/10.1016/ S0090-4295(01)01595-3
8. Lee DG, Lee SJ. Delayed hemorrhage from a pseudoaneurysm after blunt renal trauma. Int J Urol. 2005 Oct;12(10):909-11. http:// dx.doi.org/10.1111/j.1442-2042.2005.01179.x

9. Saad NEA, Saad WEA, Davies MG, Waldman DL, Fultz PJ, Rubens DJ. Pseudoaneurysmsand the role of minimally invasive techniques in their management. Radiographics. 2005;25:S173-S189. http:// dx.doi.org/10.1148/rg.25si055503

10. Patterson DE, Segura WJ, LeRoy AJ, Benson RC Jr, May G The etiology and treatment of delayed bleeding following percutaneous lithotripsy. J Urol. 1985;133:447-451.

11. Wright JL, Porter JR. Renal artery pseudoaneurysm after laparoscopic partial nephrectomy. Urology. 2005 Nov;66(5):1109. http://dx.doi.org/10.1016/j.urology.2005.05.043

12. Ansari MS, Dodamani D, Seth A. Giant pseudoaneurysm of posterior division of renal artery: a rare complication of pyelolithotomy. Int Urol Nephrol. 2001;32(3):337-40. http:// dx.doi.org/10.1023/A:1017525620121

Correspondence Leandro Moreno Silveira Da Silva Rua Viçoso Jardim, 89 - Cubango CEP 24140-169 - Niterói (RJ) Brazil E-mail:Imorenoo@gmail.com

Author information

RAVM is a vascular surgeon at Hospital Adventista Silvestre, Hospital Servidores do Estado - RJ, and Hospital Universitário Antônio Pedro MJMP is a vascular surgeon at and head of the Vascular Surgery Service of Hospital Adventista Silvestre. He is also a physician at Hospital Universitário Antônio Pedro. LMSS is a resident physician in Clinical Oncology at Instituto Nacional do Câncer -INCA. $A B S$ is a resident physician in General Surgery at Hospital Universitário Antônio Pedro.

Author's contributions Conception and design: RAVM, MJMP Writing the article: LMSS, ABS Critical revision of the article: RAVM, MJMP, LMSS, ABS Final approval of the article*: RAVM, MJMP, LMSS, ABS Overall responsibility: RAVM

${ }^{* *}$ All authors have read and approved the final version submitted to J Vasc Bras. 